Kibrewossen Tesfagiorgis, Tesfamichael Gebreyohannes, De Smedt, F., Moeyersons, J., Miruts Hagos, Nyssen, J.,, Deckers, J., 2011. Evaluation of groundwater resources in the Geba basin, Ethiopia. Bulletin of Engineering Geology and the Environment, 70: 461-466.

\title{
Evaluation of the groundwater resources in the Geba basin, Ethiopia
}

Kibrewossen Tesfagiorgis ${ }^{1,2}$, Tesfamichael Gebreyohannes ${ }^{1,3}$, Florimond De Smedt $^{1}$, Jan Moeyersons ${ }^{4}$, Miruts Hagos ${ }^{3}$, Jan Nyssen ${ }^{5}$, and Jozef Deckers ${ }^{6}$

${ }^{1}$ Department of Hydrology and Hydraulic Engineering, Vrije Universiteit Brussel, Pleinlaan 2, 1050 Brussels, Belgium.

${ }^{2}$ NOAA-CREST Center, City College of New York, T-107 Steinman Hall, 140th St \& Convent Ave, New York, NY 10031, USA.

${ }^{3}$ Mekelle University, PO Box 231, Mekelle, Ethiopia

${ }^{4}$ Royal Museum for Central Africa, B-3080 Tervuren, Belgium

${ }^{5}$ Department of Geography, Ghent University, Krijgslaan 281-S8, B-9000 Gent, Belgium

${ }^{6}$ Department of Earth and Environmental Sciences, Division for Land and Water Management, KU Leuven, Celestijnenlaan 200E, B-3001 Leuven, Belgium

Corresponding author’s email: ktesfagiorgis@gc.cuny.edu

\section{Abstract}

This paper presents an assessment of the groundwater resources in the Geba basin, Ethiopia. Hydrogeological characteristics are derived from a combination of GIS and field survey data. MODFLOW groundwater model in PMWIN environment is used to simulate the movement and distribution of groundwater in the basin. Despite the limited data available, by simplifying the model as a single layered semi-confined groundwater system and by optimising the transmissivity of the different lithological units, a realistic description of the groundwater flow is obtained. It is concluded that $30,000 \mathrm{~m}^{3} / \mathrm{d}$ of groundwater can be abstracted in the Geba basin for irrigation in a sustainable way, in locations characterised by shallow groundwater in combination with aquitard type lithological units.

Keywords: Groundwater modelling, Transmissivity, Geba basin, Ethiopia 


\section{Introduction}

Rainfall in Ethiopia is varying highly and erratic in time and space (Yazew 2005). As a consequence, precipitation is generally insufficient to sustain the agriculture needed to alleviate food insecurity, and it becomes very important to develop and manage all other available water resources. Groundwater is one of the renewable water resources that can be exploited in a sustainable way to help rural communities in terms of clean domestic water and irrigation.

This paper discusses the groundwater potential of the Geba basin (Fig. 1), Tigray region, northern Ethiopia. The Geba river basin is about $5,150 \mathrm{~km}^{2}$, and forms part of the Tekeze-Atbara river basin, a tributary of the Blue Nile. The main economy of the area is agriculture, which accounts for more than $40 \%$ of the GDP and $80 \%$ of the labour force. Water is most crucial to support and sustain crop growth, and irrigation is often required (Leul 1994; Gemechu 2006). Hence, assessing the location and potential of additional resources as groundwater is essential. However, lack of long-term meteorological, hydrological, and hydraulic data in the basin makes accurate assessment of groundwater resources a difficult challenge.

Some groundwater investigations have been undertaken in the Geba basin by federal and regional authorities, local NGOs, or university departments. Chernet and Eshete (1982) performed some hydrogeological mapping around Mekelle (Fig. 1), the regional capital of Tigray. DEVECON (1992) investigated the water resources potential of the Mekelle area as part of the Five Towns Water Supply and Sanitation project of the Ministry of Water Resources of Ethiopia. Studies undertaken by local NGOs and the regional government for irrigation purposes have been conducted by REST (1996) and COSAERT (2001). NEDECO (1997) investigated the Tekeze river basin and described the water resources potential by borehole drilling of up to $300 \mathrm{~m}$ deep at several places in the Mekelle area. Hussein (2000) investigated the hydrogeology of the Aynalem well field, which supplies Mekelle with potable water. Gebregziabher (2003) used geophysical techniques as seismic refraction and magnetic and electrical profiling to investigate the hydrogeology of the Aynalem basin. WWDSE (2006) performed some hydro-meteorological, geological, and hydrogeological investigations around Mekelle, supplemented by a quasi-three dimensional groundwater flow 
model. All of these studies only provide local and fragmental information, while a comprehensive insight in the groundwater resources of the Geba basin remains largely unknown. In this study the groundwater resources of the Geba basin are investigated using groundwater flow modelling integrated with GIS derived basin characteristics.

\section{Methods}

\section{Development of Hydrogeological Data}

The Geba basin is characterized by rugged terrain, with topography ranging from 960 to $3280 \mathrm{~m}$. A digital elevation map (DEM), shown in Fig. 2, was derived from NASA SRTM data with 3 arc-second or a resolution of $90 \mathrm{~m}$ by $90 \mathrm{~m}$. SRTM tiles of N12E038, N12E039, N13E38, N13E39, N14E038 and N14E039 were considered for bounding the area and subsequently preparing the DEM. For regional groundwater characterization, considerable test borings and water well-log data are required to determine the sequence and type of geological deposits. However, for the Geba basin such knowledge is lacking, except for some well-logs of the Aynalem well field, $3 \mathrm{~km}$ east of Mekelle city (DEVECON, 1992). Instead, hydrogeological characteristics were derived from a digital map, indicating 20 major lithological units in the basin. The map, shown in Fig. 3, was prepared in ArcView grid format (90 m pixel size) from a geologic map (Arkin et al. 1971), previous geological studies (Beyth 1972; Merla et al. 1979; Tesfaye and Gebretsadik 1982; Getaneh and Valera 2002; Sifeta, Roser, and Kimura 2005), field surveys, and satellite images.

In addition, 358 surface and ground water levels were recorded during the field surveys. The observation points included water levels in wells, boreholes, springs, reservoirs, and perennial river courses during base flow conditions (Fig. 4). The geographical location and elevation of these observation points were recorded by GPS. However, as the recorded elevations are liable to error, only horizontal coordinates from the GPS readings were considered accurate, while the water levels were adjusted by subtracting the water depth measured from the soil surface from the DEM values. Another problem with these observations is the erratic nature of the rainfall that causes large variations in water levels in hand dug wells, reservoirs, and streams in the region. Moreover, water levels usually are seasonal 
(REST 2005). To simplify the model, these effects were ignored on this study, and all observations were considered as steady state.

Alene (2006) applied the WetSpass model (Batelaan and De Smedt 2001) to estimate seasonal and annual groundwater recharge in the Geba basin. He found that annual recharge ranges from zero to $215 \mathrm{~mm}$ per year and varies from location to location depending on slope, soil type, land-use, and climate. On average the total annual recharge was found to be $22 \mathrm{~mm}$ per year with a standard deviation of $33 \mathrm{~mm}$, which accounts for $4 \%$ of the average annual rainfall in the area. This small amount of recharge is due to the high evapotranspiration in the region (Getnet 2005).The spatial distribution of the recharge obtained from WetSpass model was converted to a $90 \mathrm{~m}$ grid digital map as an input for the groundwater model.

\section{Groundwater Modelling}

The behaviour of the groundwater system was simulated using MODFLOW groundwater model (Harbaugh et al. 2000) in PMWIN Pro 7 environment (Chiang and Kinzelbach 2005). PMWIN Pro 7 has a capacity of a million computational cells. However, all GIS grid data available for the study are raster data with a 90 $\mathrm{m} \times 90 \mathrm{~m}$ pixel size, which results in a larger number of cells than the model capacity. As a consequence, the grid was modified to a cell size of $180 \mathrm{~m} \times 180$ $\mathrm{m}$. The number of cells in the $\mathrm{x}$ and $\mathrm{y}$ directions becomes 696 and 587 respectively, resulting in a modelled area of $125.28 \mathrm{~km}$ Easting and $105.66 \mathrm{~km}$ Northing. Active and inactive cells were defined to delineate the exact shape of the basin, and the boundary of the basin was considered as a no flow boundary condition.

The groundwater system was conceptualized as a single layered semi-confined aquifer. Hence, the following groundwater flow equation applies in a steady state

$$
\frac{\partial}{\partial \mathrm{x}}\left(\mathrm{T} \frac{\partial \mathrm{h}}{\partial \mathrm{x}}\right)+\frac{\partial}{\partial \mathrm{y}}\left(\mathrm{T} \frac{\partial \mathrm{h}}{\partial \mathrm{y}}\right)+\mathrm{R}-\mathrm{Q}=0
$$

where $\mathrm{h}$ is groundwater head or elevation $(\mathrm{m}), \mathrm{R}$ is groundwater recharge $(\mathrm{m} / \mathrm{d}), \mathrm{Q}$ is groundwater discharge $(\mathrm{m} / \mathrm{d})$, $\mathrm{x}$ and $\mathrm{y}$ are horizontal dimensions $(\mathrm{m})$, and $\mathrm{T}$ is transmissivity $\left(\mathrm{m}^{2} / \mathrm{d}\right)$, which is assumed to vary spatially depending on the 
geological conditions. Equation 1 enables to set-up a groundwater model without specifying any vertical dimensions of the ground layers. Nevertheless, this simple model concept can produce realistic results for the regionally complex groundwater flow system if transmissivity values are optimised by calibrating the model such that a good fit is obtained between simulated and observed groundwater heads.

Groundwater discharge is modelled with the drain package of MODFLOW

$\mathrm{Q}=\mathrm{C} \times \max -\mathrm{h}_{\mathrm{d}}, 0_{-}^{-}$,

where $h_{d}$ is drain level $(m)$, and $C$ is drain conductance $\left(d^{-1}\right)$. Following a procedure proposed by Batelaan and De Smedt (2004), drain levels equal to topography minus $1 \mathrm{~m}$ are imposed over the whole basin and a large value is specified for the drain conductance, so that any groundwater level reaching the ground surface within one meter results in groundwater drainage to the surface. As such, the model is able to locate automatically all drainage and discharge areas as perennial rivers, and springs, and to quantify the corresponding discharge flux with Eq. 2.

In order for the model to provide accurate results, it is necessary to calibrate uncertain parameters until observations are reproduced with confidence. Hence, the transmissivity values of the geological formations, which are believed to be the most uncertain parameters, were optimized with PEST, a parameter estimation tool embedded in PMWIN Pro. 7. The optimization process was based on comparing simulated groundwater heads with the measured water levels inventory (Fig. 4) using three error criteria: mean error (ME), mean absolute error (MAE), and root mean squared error (RMSE). The mean error is the mean difference between computed heads $h_{c}$ and observed heads $h_{o}$

$\mathrm{ME}=\frac{1}{\mathrm{n}} \sum_{\mathrm{i}=1}^{\mathrm{n}} \mathbf{6}_{\mathrm{c}}-\mathrm{h}_{\mathrm{o}} \mathrm{j}$,

The mean absolute error is the mean of the absolute value of the differences in measured and simulated heads 
$\operatorname{MAE}=\frac{1}{\mathrm{n}} \sum_{\mathrm{i}=1}^{\mathrm{n}}\left|\mathrm{h}_{\mathrm{c}}-\mathrm{h}_{\mathrm{o}}\right|_{\mathrm{i}}$

and the root mean squared error is the average of the squared differences in measured and simulated heads

$\operatorname{RMSE}=\sqrt{\frac{1}{n} \sum_{\mathrm{i}=1}^{\mathrm{n}} \mathbf{6}_{\mathrm{c}}-\mathrm{h}_{\mathrm{o}} \mathbf{z}}$,

where $\mathrm{n}$ is the number of observations.

\section{Results and Discussion}

Because of the wide spatial coverage of the basin and the large number of observations, it was not possible to optimize all transmissivity values automatically at the same time. Therefore, optimization was achieved by using 3 or 4 parameters at a time whilst other parameters were kept constant. For calibration, PEST uses RMSE as calibration criterion. Ideally, this value should be as small as zero, but for the Geba basin with complex geological conditions the RMSE target was set at $10 \mathrm{~m}$. Figure 5 shows the comparison between observed and final simulated groundwater heads. The maximum error, minimum error, mean error, mean absolute error, and the root mean squared error values obtained were $19.0 \mathrm{~m},-19.1 \mathrm{~m}, .2 .0 \mathrm{~m}, 5.7 \mathrm{~m}$ and $7.1 \mathrm{~m}$ respectively, which can be considered fair in view of the regional scale and large variation in topography. The optimised transmissivity values are given in Table 1 for each geological formation and for the river beds, which were considered as a separate unit. All transmissivity values are rather small, except for the river beds, so that none of the formations can be considered as aquifers. Largest values are obtained for alluvium, Enticho sandstone, fine intrusive, granite (obviously this refers to the weathered crust), meta-sediment, trap basalt, and upper sandstone. These formations can be considered as semi-pervious aquitards, hence, able to transmit groundwater and could be possible sources for abstracting groundwater for irrigation. The other formations have very small transmissivities and can be classified as rather impervious and are not suited for abstracting groundwater. 
Figure 6 shows the final simulated regional groundwater head distribution. The groundwater head varies from a minimum of $960 \mathrm{~m}$ around the outlet of the Geba River to maximum 3,235 $\mathrm{m}$ at the northern extreme. The map indicates that groundwater levels closely follow topography. Finally, the depth to the groundwater was estimated from the difference between topography and simulated groundwater levels, as depicted in Fig. 7. This map shows that while there are places where the groundwater is near the surface such that hand dug wells or shallow drilled wells could abstract groundwater for irrigation, in other localities groundwater is situated at depths of up to $200 \mathrm{~m}$ from the soil surface. The groundwater balance can be calculated by aggregating all groundwater flows as predicted by the model. There is only one input, recharge, which amounts in total to about $3.0 \times 10^{5} \mathrm{~m}^{3} / \mathrm{d}$ on average, and there is also only one output, groundwater drainage, which also amounts to $3.0 \times 10^{5} \mathrm{~m}^{3} / \mathrm{d}$, yielding an average river base flow of about $3.5 \mathrm{~m}^{3} / \mathrm{s}$ at the outlet of the Geba River. This latter value corresponds well with field observations (MoWR 2002). A fraction of the groundwater transmitted between recharge and discharge can be abstracted safely without causing adverse effects (Miles and Chambet 1995). This fraction can cautiously be estimated as $10 \%$, which amounts to $30,000 \mathrm{~m}^{3} / \mathrm{d}$ of groundwater that can be abstracted and used for irrigation in the Geba basin in a sustainable way. The possible sites where this can be achieved are locations with shallow groundwater, for instance less than $5 \mathrm{~m}$ below soil surface, in combination with aquitard type lithological units, which can be identified by combining Figs. 3 and 7.

\section{Conclusions}

In this study, the main objective was to investigate the distribution of groundwater in the Geba basin in Northern Ethiopia. Because of lack of detailed hydrogeological information, the groundwater system of the Geba basin was conceptualized in a simplified numerical model. However, all local variations and actual conditions were incorporated in the model by calibration of the transmissivity values for each geological unit. A steady state groundwater flow model was applied using MODFLOW model in PMWIN package. Observations of water levels collected from wells, boreholes, springs, reservoirs, and perennial 
river courses were used for calibration of the groundwater model, by optimizing the transmissivity values for each lithological unit.

The comparison of observed and predicted groundwater levels shows a good agreement, with a mean error of about $2 \mathrm{~m}$ and a root mean squared error of 7.1 $\mathrm{m}$. These results are acceptable in view of the size of the study area and lack of detailed information regarding hydrogeological conditions. From the results obtained, it can be concluded some geological formations can be considered as aquitards and could be used for groundwater abstraction, but this should be supported by local geophysical explorations. Moreover, model results also show that in many areas depth to groundwater is shallow, which would allow domestic wells to be dug for irrigation. A first and crude estimation indicates that possibly $30,000 \mathrm{~m}^{3} / \mathrm{d}$ of groundwater can be abstracted in the Geba basin in a sustainable way.

\section{References}

Alene Y (2006) GIS and remote sensing assisted water balance computation of the Geba basin, Tigray, Ethiopia. MSc thesis Water Resources Engineering, KULeuven - VUB, Belgium: 122 pp Arkin Y, Beyth M, Dow DB, Levitte M, Temesgen Haile, Tsegaye Hailu T (1971) Geological map of Mekelle sheet area ND 37-11, Tigre Province. Geological Survey, Ministry of Mines, Energy $\&$ Water Resources, Addis Ababa, Ethiopia

Batelaan O, De Smedt F (2001) WetSpass: a flexible, GIS based, distributed recharge methodology for groundwater modelling. In: Impact of Human Activity on Groundwater Dynamics, IAHS Publ 269: 11-17

Batelaan O, De Smedt F (2004) SEEPAGE, a new MODFLOW DRAIN Package. Ground Water 42: $576-588$

Beyth M (1972) Palaeozoic-Mesozoic sedimentary basin of Mekelle outlier, Northern Ethiopia. Am Ass Petrol Geol Bull 56: 2426-2439

Chernet T, Eshete G (1982) Hydrogeology of the Mekele area (ND37-11). Minstry of Mines and Energy and Ethiopian Geological Survey, Memoir No 2, Addis Ababa, Ethiopia: 49 pp.

Chiang WH, Kinzelbach W (2005) 3D-groundwater modelling with PMWIN, a simulation system for modelling groundwater flow and transport. Springer-Verlag, New York, USA: 346 pp COSAERT (Commission for Sustainable Agriculture and Environmental Rehabilitation in Tigray) (2001) Suluh valley integrated rural, agriculture and water resources development study. Identification and Reconnaissance Report, Mekelle, Ethiopia DEVECON (1992) Five towns water supply and sanitation study. Ministry of Water Resources, Addis Ababa, Ethiopia 
Gebregziabher B (2003) Integrated geophysical methods to investigate the geological structures and hydrostratigraphic unit of the Aynalem area, Southeast Mekelle. MSc thesis Addis Ababa University, Ethiopia

Gemechu A (2006) Sustainable irrigation in the Tigray highlands of Northern Ethiopia. MSc thesis Water Resources Engineering, KULeuven - VUB, Belgium: 80 pp

Getaneh W, Valera R (2002) Rare earth element geochemistry of the Antalo Supersequence in the Mekele Outlier (Tigray region, northern Ethiopia). Chemical Geology 182: 395-407

Getnet M (2005) Groundwater recharge and water balance assessment in Geba basin, Tigray, Ethiopia. MSc thesis Water Resources Engineering, KULeuven - VUB, Belgium: 78 pp Harbaugh AW, Banta ER, Hill MC, McDonald MG (2000) MODFLOW-2000, the U.S. Geological Survey modular ground-water model - User guide to modularization concepts and the ground-water flow process. US Geological Survey Open-File Report 00-92: 121 pp Hussein (2000). Hydrogeology of the Aynalem wellfield, Tigray, Northern Ethiopia. Unpublished MSc thesis, Addis Ababa University.

Leul K (1994) Need, potentials and limitations for irrigation development in Tigray. Commission for Sustainable Agricultural and Environmental Rehabilitation in Tigray, Mekelle, Ethiopia: $30 \mathrm{pp}$ Miles JC, Chambet PD (1995). Safe yield of aquifers. J Water Resour Plng and Mgmt 121: 1-8 Merla G, Abbate E, Azzaroli A, Bruni P, Canuti P, Fazzuoli M, Sagri M, and Tacconi P (1979) Comments to the geological map of Ethiopia and Somalia. Consiglio Nazionale delle Ricerche, Firenze: $95 \mathrm{pp}$ MoWR (Ministry of Water Resources of Ethiopia) (2002) Ethiopian Water Resources Management Policy. Addis Ababa, Ethiopia: 56 pp NEDECO (Netherlands Engineering Consultants) (1997) Tekeze river basin integrated development master plan project. Ministry of Water Resources, Addis Ababa, Ethiopia REST (Relief Society of Tigray) (1996) Raya valley development study project - Reconnaissance phase report, US Agency for International Development DCHA/OFDA, Mekelle, Ethiopia: 56 pp. REST (Relief Society of Tigray) (2005) Drought emergency and rehabilitation program annual report (May 2004-April 2005). US Agency for International Development DCHA/OFDA, Mekelle, Ethiopia.

Sifeta K, Roser BP, Kimura J (2005) Geochemistry, provenance, and tectonic setting of Neoproterozoic metavolcanic and metasedimentary units, Werri area, Northern Ethiopia. African Earth Sciences 41: 212-234

Tesfaye C, Gebretsadik E (1982) Hydrogeology of Mekelle Area. (pp 50). Ministry of Mines and Energy, Addis Ababa, Ethiopia

WWDSE (Water Works Design and Supervision Enterprise) (2006) Evaluation of Aynalem well field and selection of additional prospective boreholes for Mekelle Town water supply source. Report II: 140 pp Yazew E (2005) Development and management of irrigated lands in Tigray, Ethiopia. PhD thesis UNESCO-IHE Institute for Water Education. Delft, the Netherlands: 265 pp 


\section{List of Tables}

Table 1. Calibrated transmissivity values for the lithological units.

\begin{tabular}{lc}
\hline Geological Formations & $\begin{array}{c}\text { Transmissivity } \\
\left(\mathrm{m}^{2} / \mathrm{d}\right)\end{array}$ \\
\hline Adigrat Sandstone & 0.13 \\
Alluvium & $0.5-5$ \\
Dolerite sill & 0.017 \\
Enticho Sandstone & 5 \\
Fine Intrusive & 4 \\
Granite & 2.35 \\
Limestone-Marl & 0.2 \\
Marl-Limestone & 0.0016 \\
Meta-conglomerate & 0.1 \\
Meta-greywack & 0.01 \\
Meta-limestone & 1 \\
Meta-sediment & 2 \\
Meta-volcanic & 0.015 \\
River Beds & $200-500$ \\
Shale & 0.054 \\
Shale-Marl-Limestone & 0.0015 \\
Tillite & 0.1 \\
Transition & 0.1 \\
Trap Basalt & 13.8 \\
Upper Sandstone & 16 \\
\hline
\end{tabular}




\section{List of Figures}

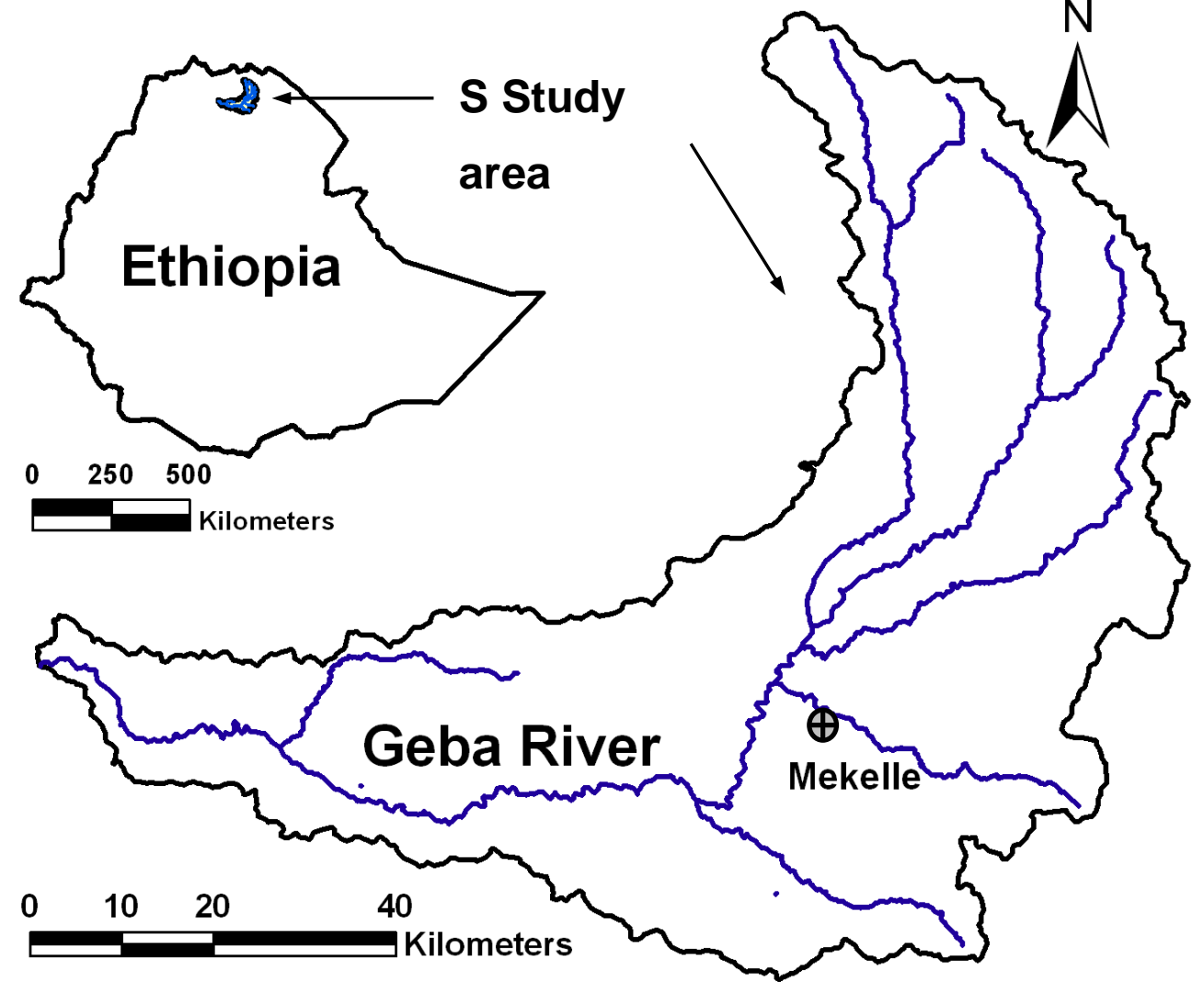

Figure 1. Location map of the Geba basin.

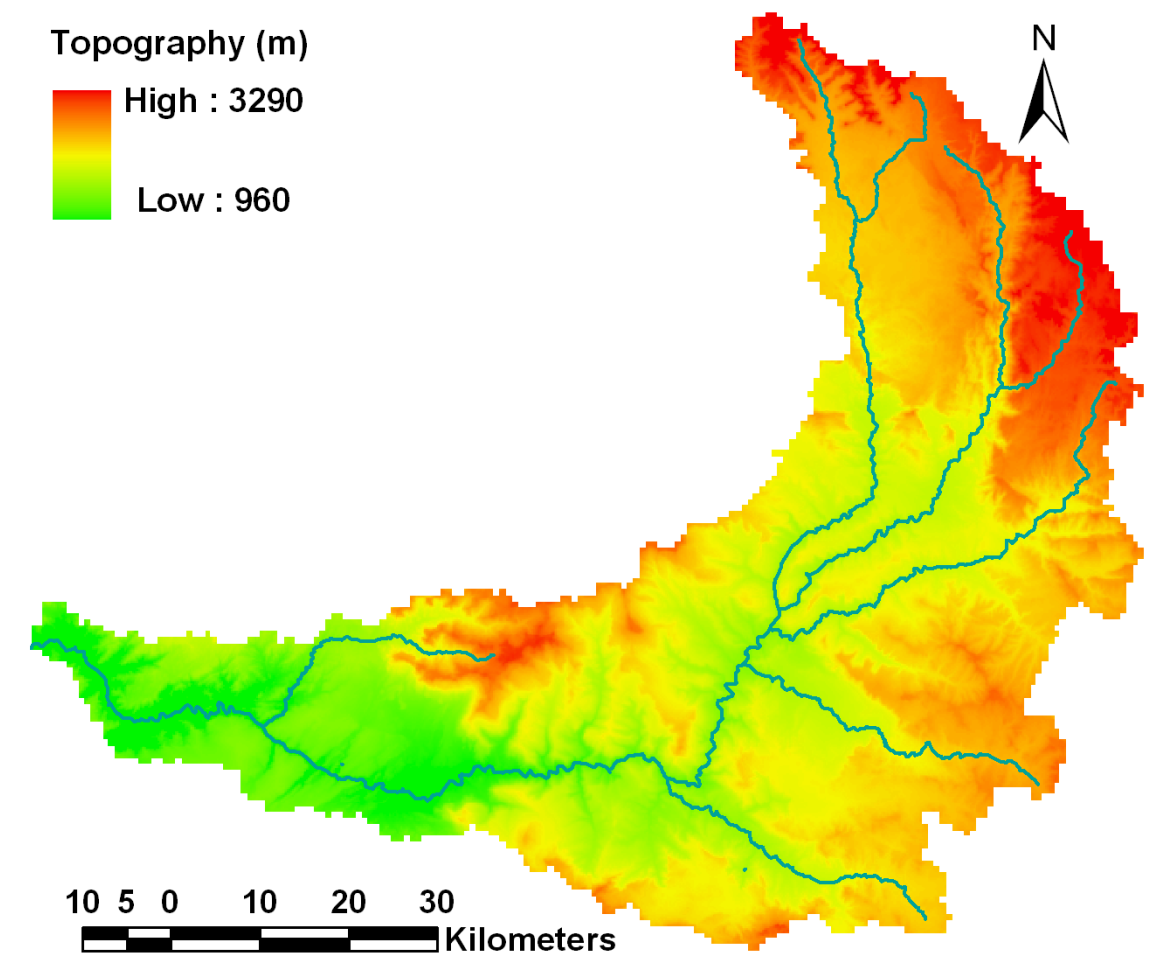

Figure 2. Topographic elevation map of the Geba basin. 


\section{Lithology}

Adigrat sandstone

Alluvium

Dolerite sill

Enticho sandstone

Fine intrusive

Granite

Limestone-Marl

Marl-Limestone

Meta-conglomerate

Meta-greywacke

Meta-limestone

Meta-sediment

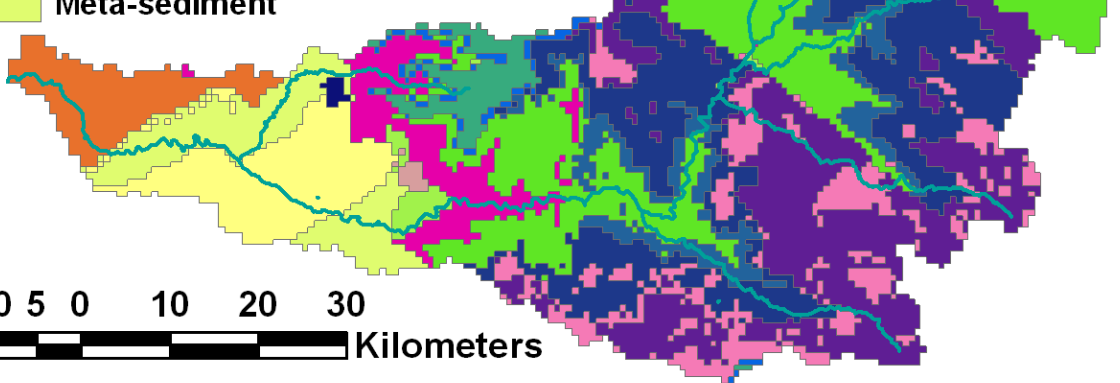

Figure 3. Map showing lithological units in the Geba basin.

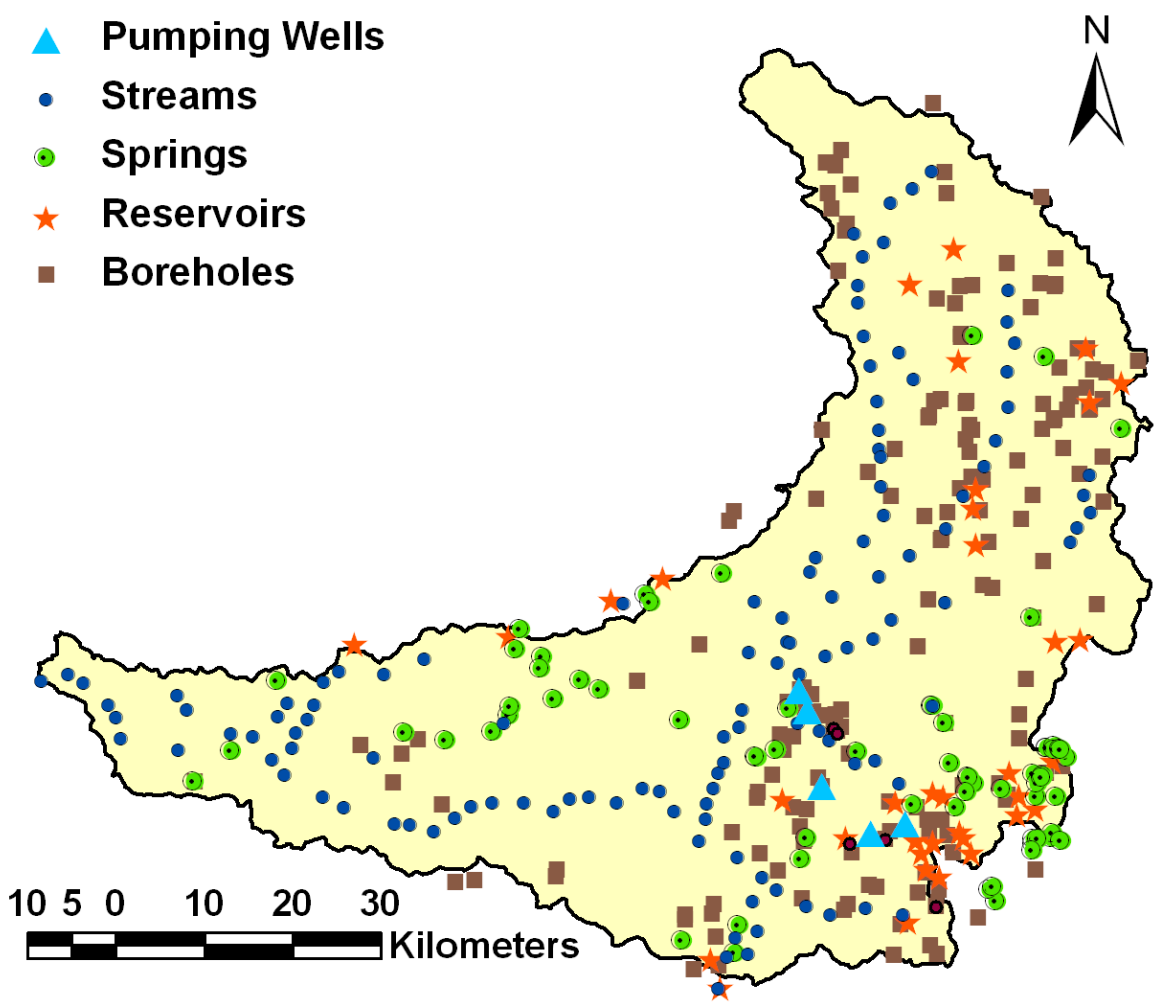

Figure 4. Locations of surface and groundwater levels observed during field campaigns. 


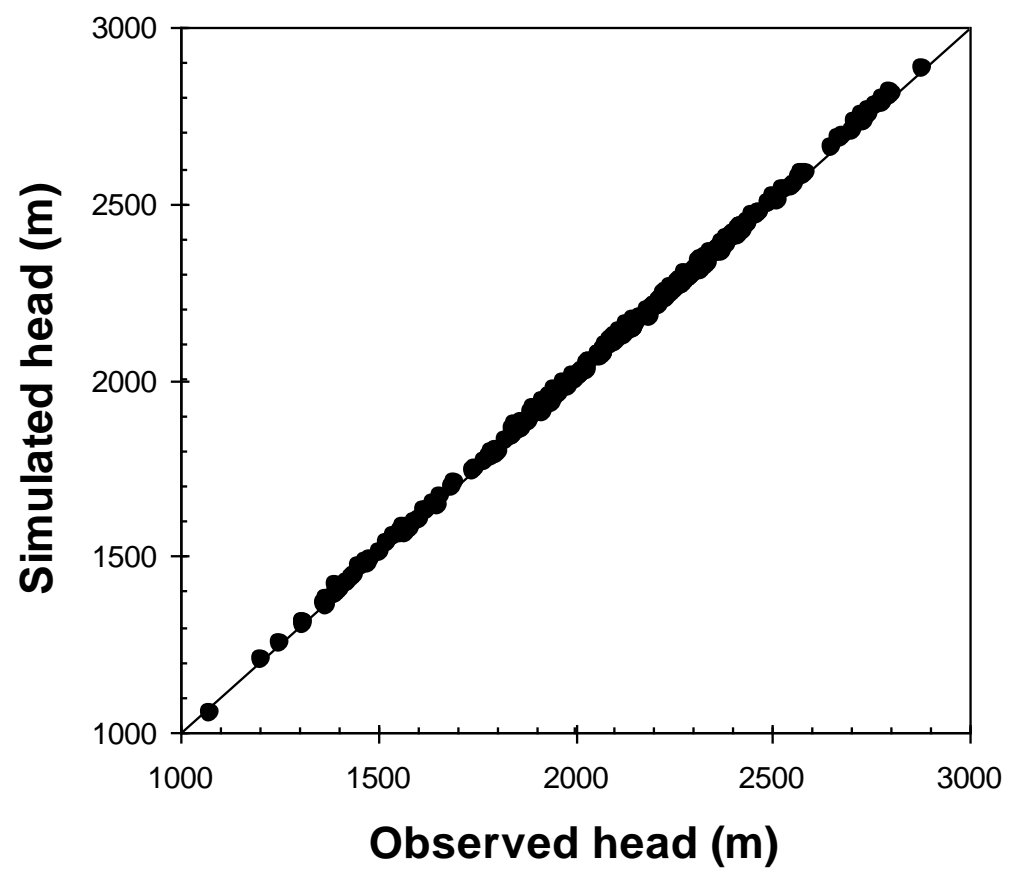

Figure 5. Scatter plot of calculated versus observed groundwater heads.

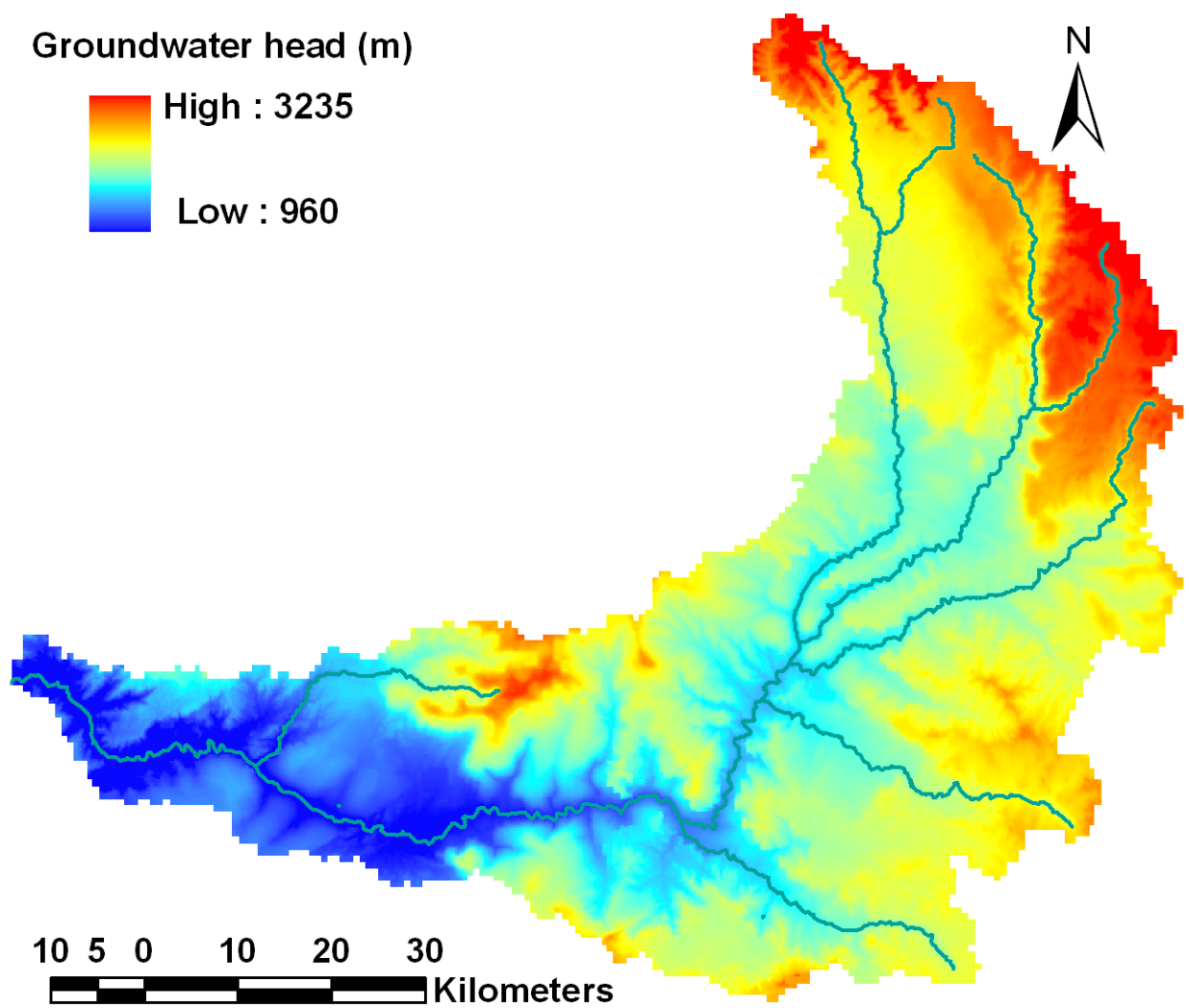

Figure 6. Simulated groundwater heads in the Geba basin. 


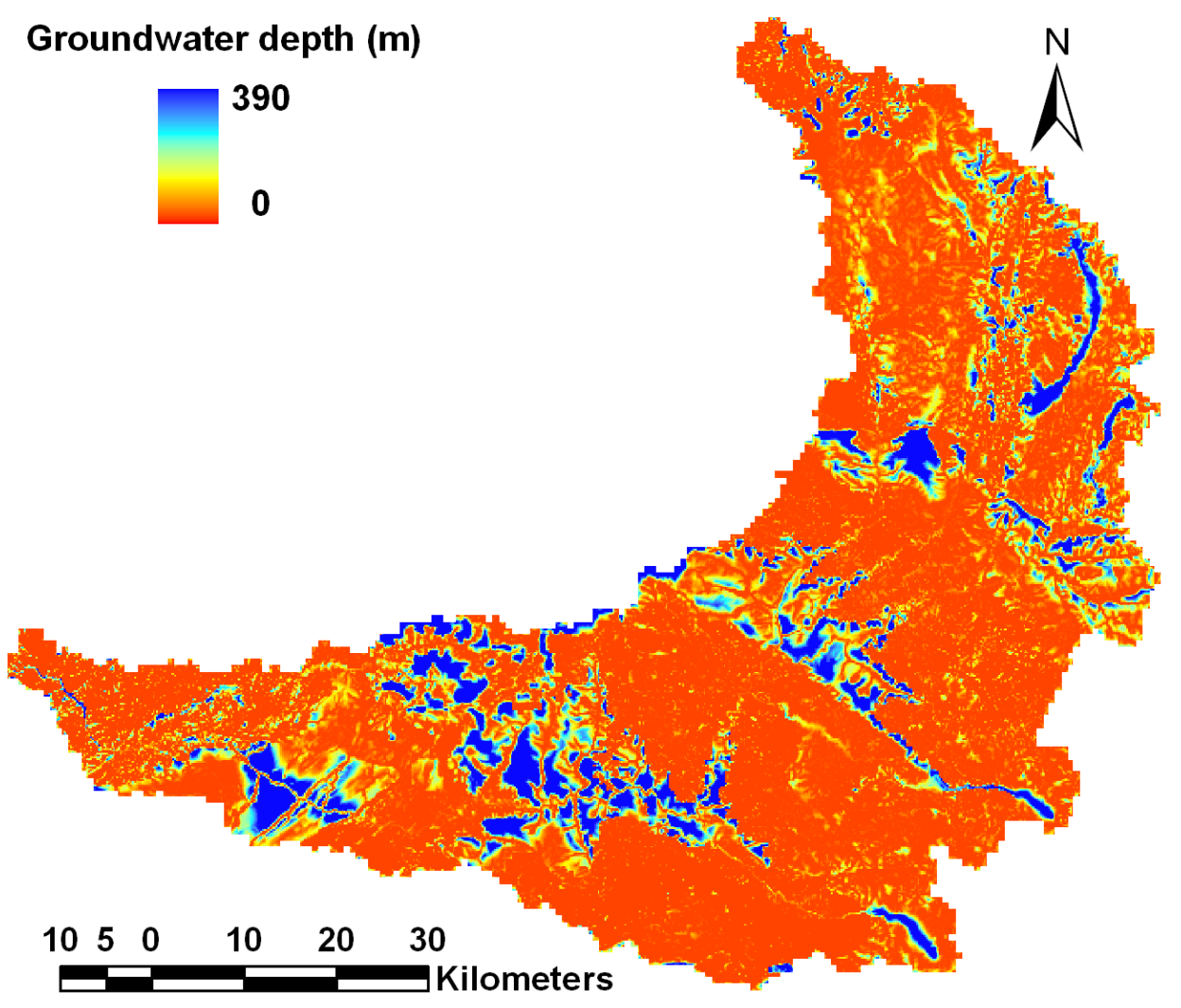

Figure 7. Depth to groundwater map of the Geba basin. 